\title{
A Taxonomy of Performance Shaping Factors for Human Reliability Analysis in Industrial Maintenance
}

\author{
Chiara Franciosi (iD, Valentina Di Pasquale (iD, Raffaele Iannone (iD, Salvatore Miranda iD \\ Department of Industrial Engineering, University of Salerno (Italy) \\ cfranciosi@unisa.it,vdipasquale@unisa.it,riannone@unisa.it,smiranda@unisa.it
}

Received: August 2018

Accepted: December 2018

\begin{abstract}
:
Purpose: Human factors play an inevitable role in maintenance activities, and the occurrence of Human Errors (HEs) affects system reliability and safety, equipment performance and economic results. The high HE rate increased researchers' attention towards Human Reliability Analysis (HRA) and HE assessment approaches. In these approaches, various environmental and individual factors influence the performance of maintenance operators affecting Human Error Probability (HEP) with a consequent variability in the success of intervention. However, a deep analysis of such factors in the maintenance field, often called Performance Shaping Factors (PSFs), is still missing. This has led the authors to systematically evaluate the literature on Human Error in Maintenance (HEM) and on the PSFs, in order to provide a shared PSF taxonomy.
\end{abstract}

Design/methodology/approach: A Systematic Literature Review (SLR) was conducted to identify and select peer-reviewed papers that provided evidence on the relationship between maintenance activities and human performance. The obtained results provided a wide overview in the field of interest, shedding light on three main research areas of investigation: methodologies for human error analysis in maintenance, performance shaping factors and maintenance error consequences. In particular, papers belonging to the area of PSFs were analysed in-depth in order to identify and classify the PSFs, with the aim of achieving the PSF taxonomy for maintenance activities. The effects of each PSF on human reliability were defined and detailed.

Findings: A total of 63 studies were selected and then analysed through a systematic methodology. 46\% of these studies presented a qualitative/quantitative assessment of PSFs through application in different maintenance activities. Starting from the findings of the aforementioned papers, a PSF taxonomy specific for maintenance activities was proposed. This taxonomy represents an important contribution for researchers and practitioners towards the improvement of HRA methods and their applications in industrial maintenance.

Originality/value: The analysis outlines the relevance of considering HEM because different error types occur during the maintenance process with non-negligible effects on the system. Despite a growing interest in HE assessment in maintenance, a deep analysis of PSFs in this field and a shared PSF taxonomy are missing. This paper fills the gap in the literature with the creation of a PSF taxonomy in industrial maintenance. The proposed taxonomy is a valuable contribution for growing the awareness of researchers and practitioners about factors influencing maintainers' performance.

Keywords: maintenance, human error, human reliability analysis, performance shaping factors, influencing factors 


\section{To cite this article:}

Franciosi, C., Di Pasquale, V., Iannone, R., \& Miranda, S. (2019). A taxonomy of performance shaping factors for human reliability analysis in industrial maintenance. Journal of Industrial Engineering and Management, 12(1), 115-132. https://doi.org/10.3926/jiem.2702

\section{Introduction}

Maintenance work quality is essential for system availability, reliability, safety and sustainability (Franciosi, Lambiase \& Miranda, 2017; Franciosi, Iung, Miranda \& Riemma, 2018), and it is a complex process that involves various technical and organisational features. The increase in complexity and size of modern systems sheds light on the relevance of human reliability in this field.

Human factors, in fact, cannot be ignored because of the high percentage of human errors (HEs) and their economic, social and safety consequences in different industrial contexts (Di Pasquale, Franciosi, Lambiase \& Miranda, 2017a). Dhillon and Liu (2006) pointed out the pressing problem of the impact of HEs on maintenance activities. For example, aviation maintenance errors account for $12-15 \%$ of the total number of accidents, and this value rises to $23 \%$ considering serious incidents (Rashid, Place \& Braithwaite, 2013), whereas Kim and Park (2009) reported that about $63 \%$ of human-related unplanned reactor trip events are associated with test and maintenance tasks. HE in maintenance tasks may result in incorrect actions, decisions or checks, and it is influenced by a variety of individual and environmental factors, with a wide variability in the success of interventions. Error consequences vary from marginal to catastrophic effects, according to the nature of the error.

Therefore, more attention has been and is still being paid to methods and approaches that measure HE or human reliability in such context (Di Pasquale, Miranda, Iannone \& Riemma, 2015a; Di Pasquale, Fruggiero, Iannone \& Miranda, 2017c; Di Pasquale, Miranda, Neumann \& Setayesh, 2018). Maintenance errors depend on many factors that are related not only to the individual characteristics of the human being, but also to the work context, the organisation or the activity that increases or decreases human performance affecting HEP (Di Pasquale, Miranda, Iannone \& Riemma, 2015c; Di Pasquale, Franciosi, Iannone, Malfettone \& Miranda, 2017b). These factors are present in the literature with several labels based on the methods or approaches to which they belong. For example, HRA methods often define them as performance shaping factors or Performance Influencing Factors (PIF), whereas other methods (e.g. Maintenance Error Decision Aid (MEDA) or expert judgement) consider these factors as HE influencing or contributing factors. A considerable range of PSFs provided by HRA approaches are available, from single-factor approaches up to more than 50 PSFs in some already existing HRA approaches (Boring, 2010; Kolaczkowski, Forester, Lois \& Cooper, 2005). However, to date, there is no consensus on which PSFs should be used and the appropriate number of PSFs to include in the methods. Boring (2010) provided a reasonable limited number of PSFs that covers the whole influence spectrum on human performance. According to Boring, for example, Standardised Plant Analysis Risk-Human (SPAR-H) (Gertman, Blackman, Marble, Byers \& Smith, 2004) or Simulator for Human Error Probability Analysis (SHERPA) (Di Pasquale et al., 2015a) methods used a classification of only eight main PSFs.

The analysis of PSFs in maintenance activities has become fundamental for identifying those that mainly influence human behaviours and the success of the activity. However, a deep analysis of such factors in the maintenance field in order to provide a shared PSF taxonomy is still missing. This has led the authors to investigate the main error contributing factors in industrial maintenance activities in order to analyse them and create a detailed taxonomy of PSFs for human reliability analysis.

This paper is organised as follows. Section 2 provides the methodology used to reach the goal. Section 3 shows the PSF taxonomy resulting from the analysis and the results' discussions. Finally, Section 4 provides the main conclusions and future research. 


\section{Methodology}

The goal of this study was reached following the proposed methodology, made up by different steps, as shown in Figure 1 and explained below.

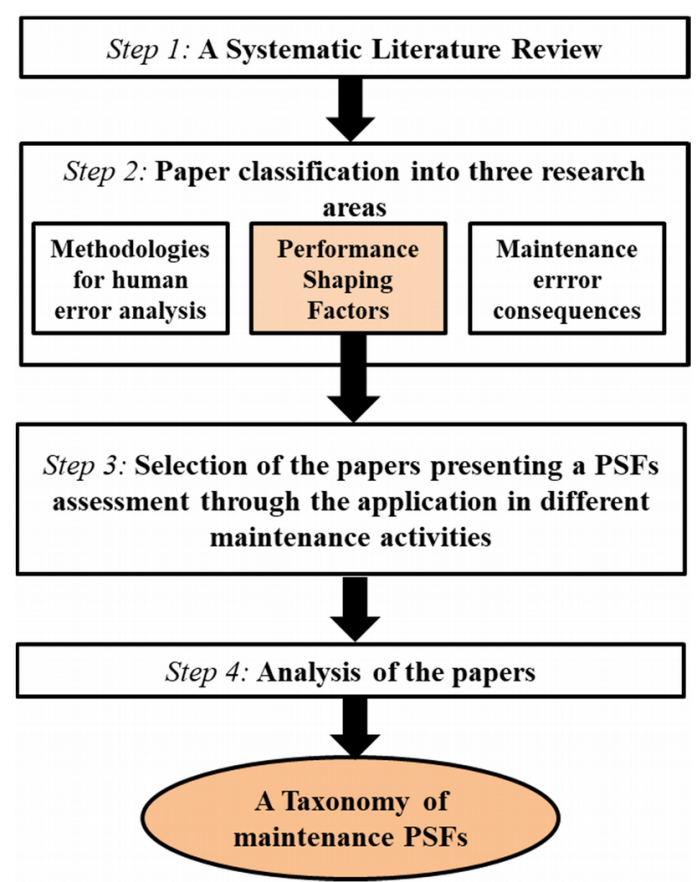

Figure 1. Methodology

Steps 1 and 2 were performed in a previous study (Di Pasquale et al., 2017b), where a systematic literature review in the field of human error in maintenance was conducted following the guidelines defined by Pires, Sénéchal, Deschamps, Loures and Perroni (2015) and Neumann, Kolus and Wells (2016). The aim was to identify and select peer-reviewed papers that provided evidence on the relationship between maintenance activities and human performance, addressing several research questions: (1) What are the industrial sectors mainly investigated in the field of interest? (2) What are the main causes and contributing factors that lead to HEs in maintenance? (3) What are the main HEM consequences? (4) How is HE evaluated and integrated within the maintenance management?

A set of keywords structured in Group A, which includes 'human error', 'human reliability analysis', 'human reliability assessment' and 'human error probability', and in Group B, which includes 'maintenance', was prepared and used to search all the papers in two scientific databases (Scopus and Web of Science). In order to achieve the final list of keywords used in the search, the keywords of each group were linked with the Boolean operator OR, whereas all groups were linked to each other with the Boolean operator AND to make the relationship among groups.

This review was limited to papers in English, published between 1997 and 2017 in peer-reviewed scientific journals or conferences. During this two-phase screening process, papers were selected according to the following defined exclusion criteria:

1. No full text is available.

2. The articles present only one of the main key concepts (maintenance and HE).

3. The papers do not establish a link between maintenance and HE.

4. HEM is a secondary aspect compared to the main purpose of the paper.

All the pertinent information presented in the studies was extracted and reported in a worksheet in order to allow for an in-depth assessment of the existing HEM state of the art and SLR results. 


\begin{tabular}{|c|c|c|}
\hline \multicolumn{2}{|r|}{ SHERPA category } & HE impact \\
\hline Available time & $\begin{array}{l}\text { Available time refers to the time required to complete the task, as well as the amount } \\
\text { of time that an operator or a team has to diagnose and act upon an abnormal event } \\
\text { (Di Pasquale et al., 2015a). }\end{array}$ & Positive/Negative \\
\hline $\begin{array}{l}\text { Cognitive } \\
\text { ergonomics }\end{array}$ & $\begin{array}{l}\text { Ergonomics refers to the equipment, displays, controls, layout, quality and quantity } \\
\text { of information available from instrumentation, as well as the interaction of the } \\
\text { operator/team with the equipment to carry out tasks. Furthermore, the aspects of } \\
\text { the human-machine interface and the adequacy or inadequacy of computer software } \\
\text { are included (Di Pasquale et al., 2015a). }\end{array}$ & Positive/Negative \\
\hline Complexity & $\begin{array}{l}\text { Complexity refers to how difficult performing a task is in a given context (Di } \\
\text { Pasquale et al., 2015a). The value of complexity relies on input from several } \\
\text { elements: } \\
\text { - General complexity } \\
\text { - Mental effort required } \\
\text { - Physical effort required from the type of activity } \\
\text { - Precision level of the activity } \\
\text { - Parallel tasks }\end{array}$ & Negative \\
\hline $\begin{array}{l}\text { Experience and } \\
\text { training }\end{array}$ & $\begin{array}{l}\text { The operator's experience and training include years of experience of the individual } \\
\text { or the team and whether or not the operator/team has been trained on the types of } \\
\text { incidents, the amount of time that passed since training and the frequency of } \\
\text { training (Di Pasquale et al., 2015a). }\end{array}$ & Positive/Negative \\
\hline Fitness for duty & $\begin{array}{l}\text { Fitness for duty refers to whether or not the operator is physically and mentally } \\
\text { suited to the task. The PSF includes fatigue, sickness, drug use, over-confidence, } \\
\text { personal problems and distractions and includes factors associated with individuals, } \\
\text { but not related to training, experience or stress (which are covered by other PSFs) } \\
\text { (Di Pasquale et al., 2015a). }\end{array}$ & Negative \\
\hline Procedures & $\begin{array}{l}\text { This PSF refers to the existence and use of formal operating procedures for the } \\
\text { tasks under consideration (Di Pasquale et al., 2015a). }\end{array}$ & Negative \\
\hline Stress & $\begin{array}{l}\text { Stress refers to the level of adverse conditions and circumstances that get more } \\
\text { difficult for the worker/team completing a task (Di Pasquale et al., 2015a). } \\
\text { Environmental and behavioural factors contribute to the identification of the } \\
\text { multiplier: } \\
\text { - Circadian rhythm } \\
\text { - Mental stress } \\
\text { - Pressure time } \\
\text { - Morkplace } \\
\text { - Lighting } \\
\text { - Noise } \\
\text { - } \text { Vibrations }\end{array}$ & Negative \\
\hline Work processes & $\begin{array}{l}\text { This PSF refers to inter-organisational factors, safety culture, work planning, } \\
\text { communication and management policies (Di Pasquale et al., 2015a). Work } \\
\text { processes also include any management, organisational or supervisory factors that } \\
\text { may affect performance. }\end{array}$ & Positive/Negative \\
\hline
\end{tabular}

Table 1. Performance shaping factors of the SHERPA method (Di Pasquale et al., 2015a)

Step 2 provided the main areas of investigation in the field of human error in maintenance defined through brainstorming among the authors following the reading of the papers with different perspectives. Therefore, the papers were classified according to three defined areas of investigation: methodologies for $\mathrm{HE}$ analysis in maintenance, PSFs and maintenance error consequences. 
Step 3 focused on papers selected through the SLR, which belong to the area of PSFs. In particular, all of these papers, which presented a qualitative/quantitative assessment of PSFs through application in different maintenance activities, were selected to be analysed in Step 4.

In Step 4, the PSF labels used in each paper were identified and reported in a worksheet. For each PSF label, its positive and/or negative impact on human reliability, the HRA approaches or other methods that present the factor and each qualitative or quantitative assessment of the factor were collected. The same number of papers was assigned to each author for the identification and description of PSF labels. Comparison among the authors, through group sessions, allowed achieving the final PSF label list.

Then, where possible, the PSF labels were classified according to the eight PSF categories of the SHERPA model described in Table 1 (Di Pasquale, Miranda, Iannone \& Riemma, 2015a, 2015b). The final classification was agreed upon by all the authors in different meeting sessions.

Following the methodology steps, the PSF taxonomy for maintenance activities, detailed with the effects of each PSF on human reliability, was achieved.

\section{Results}

\subsection{Review Results}

The database search, after removing all the duplicates, resulted in 576 papers. Based on the exclusion criteria reported in Section 2, 63 papers were selected as relevant to be analysed.

The selected papers were classified according to the defined research areas: 33 papers belong to the 'methodologies for human error analysis in maintenance' area, 43 papers belong to the 'performance shaping factors' area and 26 papers belong to the 'maintenance error consequences' area. Naturally, some papers belong to more than one area because of the interconnection among the three areas of investigation.

Taking into account the purpose of this study, the 43 papers (about 68\%) belonging to the 'PSFs' area were analysed in-depth.

In particular, among the 43 papers including the PSFs used by HRA methods and the HE influencing or contributing factors used by other methodologies, 29 papers that presented a qualitative/quantitative assessment of PSFs through application in different maintenance activities were analysed in-depth with the aim of providing the PSF taxonomy. Table 2 shows a full list of the 29 selected papers and the relative identification number (ID) that will be used in Table 2 for facilitating the readability. On the contrary, 14 of the 43 papers, belonging to the area of PSF, were excluded because a qualitative/quantitative evaluation was not provided in the content of these papers (Gibson, 2000; Latorella \& Prabhu, 2000; Hobbs \& Williamson, 2002; Lind, 2008; Kim \& Park, 2008; Dhillon, 2009, 2014; Kim \& Parks, 2009; Nicholas, 2009; Heo \& Park, 2010; Noroozi, Abbassi,, MacKinnon, Khan \& Khakzad, 2014; Abbassi, Khan, Garaniya, Chai, Chin \& Hossain, 2015; Okoh, 2015; Singh \& Kumar, 2015).

\subsection{A Taxonomy of PSFs in Industrial Maintenance}

The performed paper analysis underlined the existence of different PSF classifications in the literature, which are applied in several maintenance activities. 34 PSF labels utilised by the researchers were identified. Based on the different definitions and descriptions reported in the selected papers, they were mostly classified compared to the eight SHERPA categories, whereas 'safety equipment and support tools' was proposed as a new PSF.

Tables 3-11 show for each PSF label: the list of papers that discuss its effect on the maintainer's performance; its positive and/or negative impact on human reliability; the HRA approaches or other methods that present the factor and each qualitative or quantitative assessment of the factor, identified through the analysis. In each of these tables, the bold and underlined PSF labels represent the ones composing the final PSF taxonomy in industrial maintenance. 


\begin{tabular}{|c|l|c|l|}
\hline ID & \multicolumn{1}{|c|}{ Reference } & ID & \multicolumn{1}{|c|}{ Reference } \\
\hline 1 & Aalipour, Ayele \& Barabadi (2016) & 16 & Kovacevic, Papic, Janackovic \& Savic (2016) \\
\hline 2 & Bao \& Ding (2014) & 17 & Kumar \& Ghandi (2011) \\
\hline 3 & Bao, Wang, Huang, Xia, Chen \& Guo (2015) & 18 & Kumar, Gandhi, \& Gandhi (2015) \\
\hline 4 & Bozkurt \& Kavsaoglu (2010) & 19 & Liang, Lin, Hwang, Wang \& Patterson (2010) \\
\hline 5 & Castiglia \& Giardina (2013) & 20 & McDonnell, Balfe, Baraldi \& O’Donnell (2015) \\
\hline 6 & Chen \& Huang (2013) & 21 & Noroozi, Abbassi, MacKinnon, Khan \& Khakzad (2013a) \\
\hline 7 & Chen \& Huang (2014) & 22 & Noroozi, Khakzad, Khan, MacKinnon \& Abbassi (2013b) \\
\hline 8 & Geibel, Von Thaden \& Suzuki, (2008) & 23 & Papic \& Kovacevic (2016) \\
\hline 9 & Hameed, Khan \& Ahmed (2016) & 24 & Rankin, Hibit, Allen \& Sargent (2000) \\
\hline 10 & $\begin{array}{l}\text { Hayama, Miyachi, Nakamura, Shibata \& Kimura } \\
(2011)\end{array}$ & 25 & Rashid et al. (2013) \\
\hline 11 & Hobbs \& Williamson (2003) & 26 & Rashid, Place \& Braithwaite (2014) \\
\hline 12 & Hobbs, Williamson \& Van Dongen (2010) & 27 & Razak, Kamaruddin \& Azid (2008) \\
\hline 13 & Islam, Abbassi, Garaniya \& Khan (2016) & 28 & $\begin{array}{l}\text { Sheikhalishahi, Azadeh, Pintelon, Chemweno \& Ghaderi } \\
(2016)\end{array}$ \\
\hline 14 & Islam, Yu, Abbassi, Garaniya \& Khan (2017) & 29 & Zhou, Zhou Guo \& Zhang (2015) \\
\hline 15 & Kim \& Park (2012) & & \\
\cline { 1 - 2 } & & & \\
\hline
\end{tabular}

Table 2. List of the selected papers

The paper analysis showed that the PSFs mainly derived from common HRA methods like Cognitive Reliability and Error Analysis Method (CREAM) (Hollnagel, 1998), Human Error Assessment and Reduction Technique (HEART) (Kirwan, 1996), Success Likelihood Index Method (SLIM), SPAR-H (Gertman et al., 2004), Technique for Human Error Rate Prediction (THERP) (Swain \& Guttmann, 1983) or other methodologies that are not based on traditional HRA methods, such as MEDA or expert judgement. Moreover, the analysis allowed us to evaluate the positive and/or negative impact of each PSF on HEs and their frequency and occurrence in the industrial maintenance activities (Tables 3-11). The paper analysis pointed out some variations compared to the SHERPA categories: additional influencing factors and new or extended definitions of existing ones need to be taken into account in maintenance operations.

Some PSFs, like 'experience and training' (Table 3) and 'procedures' (Table 4), are widely taken into account in the papers as the most affecting maintainer performance. In particular, differently from the SHERPA classification, 'experience and training' are generally considered as two independent factors and both are the most impacting on HEP. The lack of experience is considered the main reason for $\mathrm{HE}$ in maintenance tasks, as reported in most of the analysed papers. 'Experience' takes into account the number of years of work, the familiarity that the operator has matured on the individual maintenance task, learning skills, knowledge acquiring, processing and situation handling. 'Training' is, instead, a key element to increase the operator's awareness of equipment, support tools, machines, components, security systems and new procedures and to eliminate time pressure issues, procedural errors and incorrect installation practices. For example, Castiglia and Giardina (2013) stated that the lack of specific training on complex systems and generally inadequate training significantly contribute to the occurrence of accidents, as there is no awareness of the possible consequences. Taking into account the importance of each of these two factors and their individual effects, 'experience' and 'training' are considered distinctly in the proposed maintenance PSF taxonomy. The other most recurring and impacting PSF on the performed task is 'procedures' PSF. This factor involves procedures' availability, illustrated parts' catalogues, information quality of maintenance documentation, work card or manuals and maintenance tasks. The procedures could be missing, not transmitted or otherwise not in an inappropriate way, thus giving rise to different interpretations and possible errors. 


\begin{tabular}{|c|c|c|c|c|}
\hline \multicolumn{5}{|c|}{ Experience and training } \\
\hline PSF label & $\begin{array}{l}\text { Literature } \\
\text { reference }\end{array}$ & $\begin{array}{c}\text { HRA } \\
\text { approaches/ } \\
\text { other } \\
\text { methods }\end{array}$ & $\begin{array}{l}\mathrm{HE} \\
\text { impact }\end{array}$ & Qualitative/quantitative assessment \\
\hline Experience & $\begin{array}{l}{[1,3,4,6,7} \\
8,9,10,13 \\
14,16,17 \\
18,20,21 \\
22,23,25 \\
27,28,29]\end{array}$ & $\begin{array}{l}\text { SLIM, } \\
\text { THERP, } \\
\text { HEART, } \\
\text { CREAM, } \\
\text { MEDA }\end{array}$ & $\begin{array}{l}\text { Positive/ } \\
\text { Negative }\end{array}$ & $\begin{array}{l}\text { [1] Operator's inexperience and the need for absolute } \\
\text { judgements are the main contributors to a high level of HEs } \\
\text { along with the shortage of time available for error detection and } \\
\text { correction. } \\
\text { [6] Experience is one of the major key factors in a visual } \\
\text { inspection performance model. } \\
\text { [8] Lack of expertise is one of the less frequent error } \\
\text { contributing factors based on incidents report of NASA } \\
\text { 'Aviation Safety Reporting System' (45/680 incidents, } 7 \% \text { ). } \\
\text { [9] Experience is the most impacting PIF (SLIM weight: } 0.25 \text { ). } \\
\text { [13] Experience along with training has the highest PSF rating } \\
\text { among the six considered PSFs. } \\
\text { [14] Experience is the most impacting contributing factor } \\
\text { (weight: } 0.40 \text { ). } \\
\text { [16] The insufficient years of service strongly affect the lack of } \\
\text { experience (rank } 4 \text { on } 20 \text { factors). } \\
\text { [22] Experience is the second most impacting PIF (SLIM } \\
\text { weight: } 0.20 \text { ). } \\
\text { [25] Skill is one of the most frequent causes of maintenance } \\
\text { errors (22/58 accidents). } \\
\text { [28] Knowledge and experience contribute } 20 \text { times to } \\
\text { fabrication errors and } 24 \text { times to installation errors. }\end{array}$ \\
\hline Training & $\begin{array}{c}{[3,4,6,7,9} \\
10,11,13 \\
14,16,17 \\
22,23,26]\end{array}$ & $\begin{array}{l}\text { SLIM, } \\
\text { MEDA }\end{array}$ & $\begin{array}{l}\text { Positive/ } \\
\text { Negative }\end{array}$ & $\begin{array}{l}\text { [6] Job training is one of the major key factors in a visual } \\
\text { inspection performance model. } \\
\text { [9] Training is the most impacting PIF (SLIM weight: } 0.20 \text { ). } \\
\text { [11] } 12.3 \% \text { of occurrences on } 619 \text { reports involve factors } \\
\text { related to inadequate training of personnel. } \\
\text { [13] Training along with experience has the highest PSF rating } \\
\text { among the six considered PSFs. } \\
\text { [14] Training is one of the three most impacting contributing } \\
\text { factors (weight: } 0.35 \text { ). } \\
\text { [16] Poor organisation of the training process and poor training } \\
\text { curricula are the most sub-factors impacting the training (ranks } \\
2 \text { and } 3 \text { on } 20 \text { factors). } \\
\text { [22] Training is the most impacting PIF (SLIM weight: } 0.25 \text { ). } \\
\text { [26] Maintainers' training is one of the most error influencing } \\
\text { factors (weight } 19 \% \text { ). }\end{array}$ \\
\hline $\begin{array}{l}\text { Experience } \\
\text { and training }\end{array}$ & {$[1,5,15,21]$} & $\begin{array}{c}\text { BN, SPAR-H, } \\
\text { HEART, } \\
\text { CREAM }\end{array}$ & $\begin{array}{l}\text { Positive/ } \\
\text { Negative }\end{array}$ & $\begin{array}{l}\text { [5] Experience and training were assumed to have an improving } \\
\text { effect. }\end{array}$ \\
\hline $\begin{array}{l}\text { Technical } \\
\text { knowledge }\end{array}$ & $\begin{array}{l}{[2,3,4,18} \\
19,24,25]\end{array}$ & MEDA & $\begin{array}{l}\text { Positive/ } \\
\text { Negative }\end{array}$ & $\begin{array}{l}{[2,4] \text { This PSF accounts for } 10-15 \% \text { of all contributing factors }} \\
\text { considered. } \\
{[24] \text { Technical knowledge is an influencing factor on } 23 \text { of the }} \\
74 \text { error investigations. } \\
\text { [25] Knowledge is one of the most frequent causes of } \\
\text { maintenance errors }(16 / 58 \text { accidents). }\end{array}$ \\
\hline
\end{tabular}

*This label considered 'experience and training' as a single factor without considering their individual impacts on human performance.

Table 3. Taxonomy of maintenance PSFs: experience and training factors 


\begin{tabular}{|c|c|c|c|c|}
\hline \multicolumn{5}{|c|}{ Procedures } \\
\hline PSF label & $\begin{array}{l}\text { Literature } \\
\text { reference }\end{array}$ & $\begin{array}{c}\text { HRA } \\
\text { approaches/ } \\
\text { other } \\
\text { methods }\end{array}$ & $\begin{array}{c}\mathrm{HE} \\
\text { impact }\end{array}$ & Qualitative/quantitative assessment \\
\hline Procedures & $\begin{array}{c}{[1,2,4,5,8,} \\
10,11,15,17 \\
18,1921,24 \\
25,26,28,29]\end{array}$ & $\begin{array}{c}\text { MEDA, } \\
\text { SPAR-H, BN, } \\
\text { HEART }\end{array}$ & Negative & $\begin{array}{l}\text { [1] The experts' recommendations about procedures, } \\
\text { applied to the case study, reduced the human error } \\
\text { probability. } \\
\text { [4] The main contributing factor, in different years of } \\
\text { observation and for three case studies, is information (work } \\
\text { card, procedures, manuals, etc) because the information is } \\
\text { not used during the maintenance actions. } \\
\text { [8] 'Document and procedure' is one of the most frequent } \\
\text { error contributing factors based on incidents report of } \\
\text { NASA 'Aviation Safety Reporting System' ( } 130 / 680 \\
\text { incidents, } 19 \% \text { ). } \\
\text { [11] } 11.4 \% \text { of occurrences on } 619 \text { reports involve } \\
\text { procedures (poorly designed, poorly documented, or non- } \\
\text { existent procedures). } \\
\text { [19] Work process/procedures not followed (this happens } \\
\text { six times in } 24 \text { months and is considered as one of the } \\
\text { most impacting factors). } \\
\text { [24] Information is an influencing factor on } 37 \text { of the } 74 \\
\text { error investigations. } \\
\text { [25] Inadequate documents are one of the most frequent } \\
\text { causes of maintenance errors ( } 31 / 58 \text { accidents). } \\
\text { [26] Documentation is a less error influencing factor } \\
\text { (weight: } 5 \% \text { ). } \\
\text { [28] Procedure usage contributes } 35 \text { times to installation } \\
\text { errors and } 45 \text { times to expected wear and tear. }\end{array}$ \\
\hline $\begin{array}{l}\text { Information } \\
\text { quality }\end{array}$ & $\begin{array}{c}{[1,2,5,6,7} \\
16,19,21,23 \\
24]\end{array}$ & $\begin{array}{l}\text { BN, MEDA, } \\
\text { HEART }\end{array}$ & Negative & $\begin{array}{l}\text { [6] Visual information is the first major key factor in a } \\
\text { visual inspection performance model. } \\
\text { [16] Inappropriate information involves four sub-factors: } \\
\text { inadequate diagnostic equipment, ambiguous guidelines, } \\
\text { lack of guidelines and incomplete guidelines, ranked, } \\
\text { respectively, as 5, 10, } 15 \text { and } 17 \text { on } 21 \text { factors considered. }\end{array}$ \\
\hline
\end{tabular}

Table 4. Taxonomy of maintenance PSFs: procedures factor

'Stress' (Table 5), 'work processes' (Table 6) and 'fitness for duty' (Table 7) are relevant and they are composed of several PSF labels. Regarding 'stress' PSF, time pressure, circadian rhythm, environment, microclimate, lighting, noise and distraction/interruption were identified as the main PSFs. While the work environment depends on the specific context and could be less relevant, pressure time results in a significant contribution to the errors in maintenance activities. Instead, regarding 'work processes' PSF, the presence of maintenance teams makes their communication and coordination essential, and the presence of good leadership or supervision is crucial for the correct execution of maintenance processes. Finally, 'fitness for duty' PSF in maintenance involves different factor labels such as physical and mental fitness, illness, complacency and motivation. In particular, these last two factors critically influence the maintenance technicians. 


\begin{tabular}{|c|c|c|c|c|}
\hline \multicolumn{5}{|c|}{ Stress } \\
\hline PSF label & $\begin{array}{l}\text { Literature } \\
\text { reference }\end{array}$ & $\begin{array}{l}\text { HRA } \\
\text { approaches/ } \\
\text { other } \\
\text { methods }\end{array}$ & HE & Qualitative/quantitative assessment \\
\hline Stress & $\begin{array}{c}{[1,3,10,13,18} \\
21,22]\end{array}$ & $\begin{array}{l}\text { HEART, } \\
\text { SPAR-H, } \\
\text { SLIM }\end{array}$ & Negative & $\begin{array}{l}\text { [22] Stress is one of the impacting PIFs (SLIM weight: } \\
0.15) \text {. }\end{array}$ \\
\hline $\begin{array}{l}\text { Environment/f } \\
\text { acilities }\end{array}$ & $\begin{array}{l}{[2,3,4,8,9,11} \\
13,16,17,18 \\
20,21,22,24]\end{array}$ & MEDA, SLIM & Negative & $\begin{array}{l}\text { [8] Environment is one of the less frequent error } \\
\text { contributing factors based on incidents report of NASA } \\
\text { 'Aviation Safety Reporting System' ( } 39 / 680 \text { incidents, } \\
6 \% \text { ). } \\
\text { [9] Work environment (SLIM) is the most impacting PIF } \\
\text { (SLIM weight: } 0.20) \text {. } \\
\text { [11] } 5.4 \% \text { of occurrences on } 619 \text { accident reports involve } \\
\text { environment. } \\
\text { [22] Work environment (SLIM) is one of the impacting } \\
\text { PIFs (SLIM weight: } 0.15) \text {. } \\
\text { [24] 'Environment and facilities' is an influencing factor } \\
\text { on } 28 \text { of the } 74 \text { error investigations. }\end{array}$ \\
\hline Pressure time & $\begin{array}{l}{[3,6,7,8,9,11} \\
19,28,29]\end{array}$ & $\begin{array}{l}\text { CREAM, } \\
\text { HEART, } \\
\text { MEDA, SLIM }\end{array}$ & Negative & $\begin{array}{l}\text { [8] Time pressure is one of the most frequent error } \\
\text { contributing factors based on incidents report of NASA } \\
\text { 'Aviation Safety Reporting System' (146/680 incidents, } \\
22 \% \text { ). } \\
\text { [9] Time pressure (SLIM) is the most impacting PIF } \\
\text { (weight: } 0.20) \text {. } \\
\text { [11] } 23.5 \% \text { of occurrences on } 619 \text { reports involve } \\
\text { pressure time, which is the most influencing factor. } \\
\text { [28] Time pressure contributes } 23 \text { times to installation } \\
\text { errors. }\end{array}$ \\
\hline $\begin{array}{l}\text { Circadian } \\
\text { rhythm }\end{array}$ & {$[6,7,12,15,21]$} & HEART & Negative & $\begin{array}{l}\text { [12] Circadian rhythm mainly involves skill-based errors, } \\
\text { which are most frequent in the early hours of the } \\
\text { morning, decreasing in frequency during the day, whereas } \\
\text { rule-based mistakes, knowledge-based mistakes and } \\
\text { procedure violations do not show this clear trend during } \\
\text { the day. }\end{array}$ \\
\hline Lighting & $\begin{array}{c}{[6,7,15,18,19} \\
20]\end{array}$ & $\begin{array}{l}\text { MEDA, } \\
\text { THERP }\end{array}$ & Negative & $\begin{array}{l}\text { [6] Illumination is one of the major key factors in a visual } \\
\text { inspection performance model. }\end{array}$ \\
\hline $\begin{array}{l}\text { Noise and } \\
\text { microclimate }\end{array}$ & {$[6,7,15,20]$} & THERP & Negative & - \\
\hline $\begin{array}{l}\text { Distraction/ } \\
\text { interruption }\end{array}$ & {$[18,8]$} & - & Negative & $\begin{array}{l}\text { [8] 'Distraction/interruption' is one of the most frequent } \\
\text { error contributing factors based on incidents report of } \\
\text { NASA 'Aviation Safety Reporting System' ( } 71 / 680 \\
\text { incidents, } 10 \%) \text {. }\end{array}$ \\
\hline
\end{tabular}

Table 5. Taxonomy of maintenance PSFs: stress factor 


\begin{tabular}{|c|c|c|c|c|}
\hline \multicolumn{5}{|c|}{ Work processes } \\
\hline PSF label & $\begin{array}{l}\text { Literature } \\
\text { reference }\end{array}$ & $\begin{array}{l}\text { HRA } \\
\text { approaches/ } \\
\text { other } \\
\text { methods }\end{array}$ & $\begin{array}{l}\mathrm{HE} \\
\text { impact }\end{array}$ & Qualitative/quantitative assessment \\
\hline $\begin{array}{l}\text { Work } \\
\text { processes }\end{array}$ & {$[1,3,17,25]$} & BN, SPAR-H & $\begin{array}{l}\text { Positive/ } \\
\text { Negative }\end{array}$ & $\begin{array}{l}\text { [17] The authors considered the work process factor mainly } \\
\text { related to the maintenance culture. } \\
\text { [25] Inadequate processes are the most frequent cause of } \\
\text { maintenance errors ( } 36 / 58 \text { accidents). }\end{array}$ \\
\hline $\begin{array}{l}\text { Communicatio } \\
\mathrm{n} \text { and } \\
\text { integration/ } \\
\text { coordination }\end{array}$ & $\begin{array}{l}{[2,3,4,6,7} \\
8,10,11,15 \\
16,17,18 \\
24,28]\end{array}$ & MEDA & $\begin{array}{l}\text { Positive/ } \\
\text { Negative }\end{array}$ & $\begin{array}{l}\text { [2] Communication accounts for } 7 \% \text { of all contributing factors } \\
\text { considered. } \\
\text { [4] Poor communication is the most frequently seen } \\
\text { contributing factor in a reference period }(23 \%) \text {. } \\
\text { [8] Coordination is one of the most frequent error contributing } \\
\text { factors based on incidents report of NASA 'Aviation Safety } \\
\text { Reporting System' ( } 115 / 680 \text { incidents, } 17 \%) \text {. } \\
\text { [11] } 12.2 \% \text { of occurrences on } 619 \text { reports involve coordination. } \\
\text { [16] 'Lack of understanding of the work process' is the } 8 \text { th } \\
\text { factor on } 21 \text { influencing factors. } \\
\text { [24] Communication is an influencing factor on } 32 \text { of the } 74 \\
\text { error investigations. }\end{array}$ \\
\hline $\begin{array}{l}\text { Leadership/ } \\
\text { supervision }\end{array}$ & $\begin{array}{l}{[2,3,4,6,7} \\
8,11,17,18 \\
19,24,25 \\
26]\end{array}$ & MEDA & $\begin{array}{l}\text { Positive/ } \\
\text { Negative }\end{array}$ & $\begin{array}{l}\text { [2] Leadership/supervision accounts for } 3 \% \text { of all contributing } \\
\text { factors considered. } \\
\text { [8] Lack of vigilance is the most frequent error contributing } \\
\text { factor based on incidents report of NASA 'Aviation Safety } \\
\text { Reporting System' ( } 421 / 680 \text { incidents, } 62 \% \text { ). } \\
\text { [11] } 10.4 \% \text { of occurrences on } 619 \text { reports involve supervision. } \\
\text { [19] Leadership/supervision (this happens four times in } 24 \\
\text { months and is considered as one of the most impacting factors). } \\
\text { [24] Supervision is an influencing factor on } 12 \text { of the } 74 \text { error } \\
\text { investigations. } \\
\text { [25] Inadequate supervision is one of the most frequent causes } \\
\text { of maintenance errors (15/58 accidents). } \\
\text { [26] Supervision is the most error influencing factor (weight: } \\
29 \% \text { ). }\end{array}$ \\
\hline $\begin{array}{l}\text { Organisational } \\
\text { factors/ } \\
\text { adequacy } \\
\text { of the } \\
\text { organisation }\end{array}$ & $\begin{array}{l}{[2,4,6,7,8} \\
16,18,24 \\
26]\end{array}$ & MEDA & $\begin{array}{l}\text { Positive/ } \\
\text { Negative }\end{array}$ & $\begin{array}{l}\text { [2] Organisational factors account for } 10 \% \text { of all contributing } \\
\text { factors considered. } \\
\text { [6] Organisational culture is one of the major key factors in a } \\
\text { visual inspection performance model. } \\
\text { [8] Organisation is one of the less frequent error contributing } \\
\text { factors based on incidents report of NASA 'Aviation Safety } \\
\text { Reporting System' }(72 / 680 \text { incidents, } 11 \%) \text {. } \\
\text { [16] 'Poor organisation of the workplace' is the } 7 \text { th factor on } 21 \\
\text { influencing factors. } \\
\text { [24] Organisational environment is an influencing factor on } 19 \\
\text { of the } 74 \text { error investigations. } \\
\text { [26] Organisational process is one of the most error influencing } \\
\text { factors (weight: } 14 \% \text { ). }\end{array}$ \\
\hline Safety culture & $\begin{array}{c}{[5,10,16} \\
18,21]\end{array}$ & HEART & $\begin{array}{l}\text { Positive/ } \\
\text { Negative }\end{array}$ & $\begin{array}{l}{[5,21] \text { The authors considered mismatches between perceived }} \\
\text { and actual risks. }\end{array}$ \\
\hline
\end{tabular}

Table 6. Taxonomy of maintenance PSFs: work processes factor 


\begin{tabular}{|c|c|c|c|c|}
\hline \multicolumn{5}{|c|}{ Fitness for duty } \\
\hline PSF label & $\begin{array}{l}\text { Literature } \\
\text { reference }\end{array}$ & $\begin{array}{c}\text { HRA } \\
\text { approaches/ } \\
\text { other } \\
\text { methods }\end{array}$ & $\begin{array}{l}\mathrm{HE} \\
\text { impact }\end{array}$ & Qualitative/quantitative assessment \\
\hline $\begin{array}{l}\text { Fitness for } \\
\text { duty }\end{array}$ & $\begin{array}{c}{[1,2,4,6,7,8} \\
10,16,18,24 \\
27]\end{array}$ & $\begin{array}{l}\text { SPAR-H, } \\
\text { MEDA, } \\
\text { SLIM }\end{array}$ & Negative & $\begin{array}{l}\text { [2] Individual factors account for } 26 \% \text { of all contributing } \\
\text { factors considered. } \\
\text { [6] Physical, mental and visual fatigue are three of the major } \\
\text { key factors in a visual inspection performance model. } \\
\text { [8] Inappropriate attitude is one of the less frequent error } \\
\text { contributing factors based on incidents report of NASA } \\
\text { 'Aviation Safety Reporting System' ( } 25 / 680 \text { incidents, } 4 \% \text { ). } \\
\text { [24] 'Factors affecting individual performance' is an } \\
\text { influencing factor on } 26 \text { of the } 74 \text { error investigations. }\end{array}$ \\
\hline $\begin{array}{l}\text { Physical } \\
\text { fitness }\end{array}$ & $\begin{array}{c}{[3,8,11,14} \\
17,21,22]\end{array}$ & $\begin{array}{l}\text { HEART, } \\
\text { SLIM }\end{array}$ & Negative & $\begin{array}{l}\text { [8] From the statistics of NASA 'Aviation Safety Reporting } \\
\text { System' incidents report, it results that the physical state is } \\
\text { the less frequent error contributing factor }(16 / 680 \\
\text { incidents, } 2 \%) \text {. } \\
\text { [11] } 12.2 \% \text { of the occurrences on } 619 \text { reports involve } \\
\text { mental and physical fatigue. } \\
\text { [14] 'Mental and physical fatigue' is one of the three most } \\
\text { impacting contributing factors (weight: } 0.25) \text {. } \\
\text { [22] Physical capability and condition have the lowest } \\
\text { weight (SLIM) among the PIFs considered in the study } \\
\text { (weight: } 0.10) \text {. }\end{array}$ \\
\hline Mental fitness & $\begin{array}{l}{[10,11,14,18,} \\
17]\end{array}$ & - & Negative & $\begin{array}{l}\text { [11] } 12.2 \% \text { of the occurrences on } 619 \text { reports involve } \\
\text { mental and physical fatigue. } \\
\text { [14] 'Mental and physical fatigue' is one of the three most } \\
\text { impacting contributing factors (weight: } 0.25 \text { ). }\end{array}$ \\
\hline Complacency & {$[16,19,27]$} & $\begin{array}{l}\text { MEDA, } \\
\text { SLIM }\end{array}$ & Negative & $\begin{array}{l}\text { [16] 'Failure to follow technical maintenance instructions' is } \\
\text { the most influencing factor on } 21 \text { factors considered in the } \\
\text { study. } \\
\text { [19] Complacency (this happens six times in } 24 \text { months and } \\
\text { is considered as one of the most impacting factors). }\end{array}$ \\
\hline Motivation & {$[16,18,27]$} & SLIM & $\begin{array}{l}\text { Positive/ } \\
\text { Negative }\end{array}$ & $\begin{array}{l}\text { [18] The fuzzy cognitive map has highlighted that the } \\
\text { degree of interaction among the factors will change its } \\
\text { intensity according to the operator's motivation. Hence, the } \\
\text { authors pointed out that a little enhancement in motivation } \\
\text { significantly influenced the other factors in a positive } \\
\text { manner. } \\
\text { [27] Motivation is the most important factor to successfully } \\
\text { perform tasks. }\end{array}$ \\
\hline Illness & {$[11,18,21]$} & HEART & Negative & $\begin{array}{l}\text { [11] Worker performance is influenced by medical } \\
\text { conditions or by sensorial or physiological deficits. }\end{array}$ \\
\hline
\end{tabular}

Table 7. Taxonomy of maintenance PSFs: fitness for duty factor

Moreover, the 'cognitive ergonomics' (Table 8) PSF, in maintenance processes, includes system and interface design, control and displays, comparability, accessibility, visibility and disassemblability. However, these were not defined as significant factors in the maintenance process, differently from repetitive and heavy production tasks, where cognitive ergonomics is a key factor. 


\begin{tabular}{|c|c|c|c|c|}
\hline \multicolumn{5}{|c|}{ Cognitive ergonomics } \\
\hline PSF label & $\begin{array}{l}\text { Literature } \\
\text { reference }\end{array}$ & $\begin{array}{l}\text { HRA } \\
\text { approaches/ } \\
\text { other } \\
\text { methods }\end{array}$ & $\begin{array}{c}\mathrm{HE} \\
\text { impact }\end{array}$ & Qualitative/quantitative assessment \\
\hline Ergonomics & $\begin{array}{c}{[1,3,5,6,7} \\
15,21]\end{array}$ & $\begin{array}{l}\text { HEART, } \\
\text { SPAR-H, } \\
\text { CREAM, BN }\end{array}$ & $\begin{array}{l}\text { Positive/ } \\
\text { Negative }\end{array}$ & $\begin{array}{l}\text { [5] Adequacy of the man-machine interface and operational } \\
\text { support. } \\
\text { [6] Detection distance is one of the major key factors in a visual } \\
\text { inspection performance model. }\end{array}$ \\
\hline System design & $\begin{array}{l}{[2,3,4,8} \\
17,18,20 \\
24,25,26 \\
\quad 29]\end{array}$ & MEDA & $\begin{array}{l}\text { Positive/ } \\
\text { Negative }\end{array}$ & $\begin{array}{l}\text { [8] Design is one of the less frequent error contributing factors } \\
\text { based on incidents report of NASA 'Aviation Safety Reporting } \\
\text { System' ( } 17 / 680 \text { incidents, } 2.5 \%) \text {. } \\
\text { [18] This category includes interface design, control and } \\
\text { displays, comparability, accessibility, visibility and } \\
\text { disassemblability. } \\
\text { [24] Airplane design/configuration is an influencing factor on } \\
22 \text { of the } 74 \text { error investigations. } \\
\text { [25] Inadequate A/C design is one of the most frequent causes } \\
\text { of maintenance errors ( } 21 / 58 \text { accidents). } \\
\text { [26] Aircraft design is one of the most error influencing factors } \\
\text { (weight: } 14 \% \text {. }\end{array}$ \\
\hline
\end{tabular}

Table 8. Taxonomy of maintenance PSFs: cognitive ergonomics factor

'Safety equipment and support tools' (Table 9) has emerged as a PSF to be taken into account for HRA in such contexts. In fact, the tools and materials used in maintenance must be available, reliable and suitable and can vary from common to very complex tools that require more attention.

\begin{tabular}{|c|c|c|c|c|}
\hline \multicolumn{5}{|c|}{ Safety equipment and support tools } \\
\hline PSF label & $\begin{array}{l}\text { Literature } \\
\text { reference }\end{array}$ & $\begin{array}{c}\text { HRA } \\
\text { approaches/ } \\
\text { other } \\
\text { methods }\end{array}$ & $\begin{array}{c}\mathrm{HE} \\
\text { impact }\end{array}$ & Qualitative/quantitative assessment \\
\hline $\begin{array}{l}\text { Safety } \\
\text { equipment } \\
\text { and support } \\
\text { tools }\end{array}$ & $\begin{array}{c}{[1,2,4,6,7} \\
8,10,11,20 \\
21,24,28]\end{array}$ & $\begin{array}{c}\text { MEDA, } \\
\text { HEART, } \\
\text { THERP, BN }\end{array}$ & $\begin{array}{l}\text { Positive/ } \\
\text { Negative }\end{array}$ & $\begin{array}{l}\text { [4] 'Equipment and tools' is the main contributing factor in one } \\
\text { year of observation in a specific case study }(23 \%) \text {. } \\
\text { [6] Equipment is one of the major key factors in a visual } \\
\text { inspection performance model. } \\
\text { [8] 'Equipment and parts' is one of the less frequent error } \\
\text { contributing factors based on incidents report of NASA } \\
\text { 'Aviation Safety Reporting System' ( } 37 / 680 \text { incidents, } 5 \%) \text {. } \\
\text { [11] } 14.4 \% \text { of the occurrences on } 619 \text { reports involve } \\
\text { equipment, which involves poorly designed or maintained } \\
\text { equipment or tools, or a lack of necessary equipment, including } \\
\text { aircraft spare parts. } \\
\text { [24] Equipment/tools/safety equipment is an influencing factor } \\
\text { on } 20 \text { of the } 74 \text { error investigations. }\end{array}$ \\
\hline
\end{tabular}

Table 9. Taxonomy of maintenance PSFs: safety equipment and support tools factor

Other PSFs, such as 'available time' (Table 10) and 'complexity' (Table 11), are present in the literature, but with a lower frequency, given the least impact on maintainers' performances. 


\begin{tabular}{|c|c|c|c|c|}
\hline \multicolumn{5}{|c|}{ Available time } \\
\hline PSF label & $\begin{array}{l}\text { Literature } \\
\text { reference }\end{array}$ & $\begin{array}{l}\text { HRA } \\
\text { approaches/ } \\
\text { other } \\
\text { methods }\end{array}$ & $\begin{array}{l}\mathrm{HE} \\
\text { impact }\end{array}$ & Qualitative/quantitative assessment \\
\hline Available time & {$[1,10]$} & $\begin{array}{l}\text { SPAR-H, } \\
\text { THERP, BN }\end{array}$ & $\begin{array}{l}\text { Positive/ } \\
\text { Negative }\end{array}$ & $\begin{array}{l}\text { [1] Available time is equal to the time required or barely } \\
\text { adequate time (PSF multipliers }=10) \text {. }\end{array}$ \\
\hline $\begin{array}{l}\text { Shortage of } \\
\text { time available } \\
\text { for error } \\
\text { detection and } \\
\text { correction }\end{array}$ & {$[1,21]$} & HEART & Negative & $\begin{array}{l}{[1] \text { This is one of the main contributors to a high level of HE }} \\
\text { along with operator inexperience and the need for absolute } \\
\text { judgements. }\end{array}$ \\
\hline
\end{tabular}

Table 10. Taxonomy of maintenance PSFs: available time factor

Based on the descriptions, PSFs relevant to specific fields of industrial maintenance were structured in a taxonomy involving 10 PSFs underlined in Tables 3-11: time available, experience, training, stress, complexity, procedures, work processes, fitness for duty, ergonomics and safety equipment and support tools. The proposed taxonomy should be used for the assessment of the overall maintenance task, prediction of HEs and quantification of their probabilities through the integration of such taxonomy in the existing methods for human error analysis and their setting.

\begin{tabular}{|c|c|c|c|c|}
\hline \multicolumn{5}{|c|}{ Complexity } \\
\hline PSF label & $\begin{array}{l}\text { Literature } \\
\text { reference }\end{array}$ & $\begin{array}{c}\text { HRA } \\
\text { approaches/ } \\
\text { other } \\
\text { methods }\end{array}$ & $\begin{array}{l}\mathrm{HE} \\
\text { impact }\end{array}$ & Qualitative/quantitative assessment \\
\hline Complexity & $\begin{array}{l}{[1,10,15} \\
20,21]\end{array}$ & $\begin{array}{l}\text { SPAR-H, } \\
\text { HEART }\end{array}$ & Negative & - \\
\hline $\begin{array}{l}\text { Mental effort } \\
\text { required for } \\
\text { maintenance } \\
\text { activity }\end{array}$ & $\begin{array}{l}{[3,9,13,15} \\
22,25,28]\end{array}$ & SLIM & Negative & $\begin{array}{l}\text { [9] Work memory is the most impacting PIF (SLIM weight: } \\
0.15) \text {. } \\
\text { [22] Work memory is one of the impacting PIFs (SLIM weight: } \\
0.15) \text {. } \\
\text { [25] Attention/memory is one of the most frequent causes of } \\
\text { maintenance errors ( } 28 / 58 \text { accidents). } \\
\text { [28] Fatigue contributes } 51 \text { times to installation errors and } 11 \\
\text { times to fabrication errors. }\end{array}$ \\
\hline $\begin{array}{l}\text { Physical effort } \\
\text { required for } \\
\text { maintenance } \\
\text { activity }\end{array}$ & {$[3,13,15]$} & SLIM & Negative & $\begin{array}{l}\text { [15] The mismatch between work requirements (speed, strength } \\
\text { and precision) and motor capabilities may affect human errors. }\end{array}$ \\
\hline $\mathrm{Job} / \mathrm{task}$ & {$[2,4,19,24]$} & MEDA & Negative & $\begin{array}{l}\text { [2] Job/task accounts for } 9 \% \text { of all contributing factors } \\
\text { considered. } \\
\text { [4] Job/task is the main contributing factor in one year of } \\
\text { observation in a specific case study }(23 \%) \text {. } \\
\text { [24] Job/task is an influencing factor on } 31 \text { of the } 74 \text { error } \\
\text { investigations. }\end{array}$ \\
\hline $\begin{array}{l}\text { Number of } \\
\text { simultaneous } \\
\text { goals }\end{array}$ & {$[5]$} & CREAM & Negative & - \\
\hline
\end{tabular}

Table 11. Taxonomy of maintenance PSFs: complexity factor 


\section{Conclusions and Future Research}

Despite the growing interest in HE assessment in maintenance, a deep analysis of PSFs in this field and a shared PSF taxonomy are missing. In this study, we identified and analysed the papers presenting a PSF assessment through application in different maintenance activities, investigating and providing a wide overview of the main PSFs. Then, the factors were classified compared to already existing PSF categories, including additional influencing factors or extending their descriptions for the specific maintenance field in order to provide a detailed PSF taxonomy.

The proposed taxonomy is useful for several qualitative and quantitative objectives in different research and practical fields. First, this taxonomy is a valuable contribution for growing the awareness of researchers and practitioners about factors influencing maintainers' performances. These factors should be taken into account in order to reduce HEs in maintenance.

The taxonomy can be integrated in already existing HRA methods in order to properly quantify and predict HEP in maintenance activities and to reduce economic and social consequences of HEs for proper maintenance management.

Considering the several similarities between the HRA theory and the recent paradigm of resilience engineering (Boring, 2009; Patriarca, Bergström, Di Gravio \& Costantino, 2018), the proposed taxonomy can support the development of resilience shaping factors, which were defined by Boring (2009) as a necessary and inevitable step towards the widespread dissemination of resilience engineering.

The developed review allowed us to obtain the final taxonomy through the detailed study of the available scientific literature. However, in order to come up with a stronger PSF taxonomy, future developments should involve an extensive validation of concepts and PSF ranks through specific case studies and the investigation of maintenance experts' knowledge with focus group interviews and ad hoc questionnaires. A further step will be to integrate the proposed taxonomy in the SHERPA model for application in the field.

\section{Declaration of Conflicting Interests}

The authors declared no potential conflicts of interest with respect to the research, authorship, and/or publication of this article.

\section{Funding}

The authors received no financial support for the research, authorship, and/or publication of this article.

\section{References}

Aalipour, M., Ayele, Y.Z., \& Barabadi, A. (2016). Human reliability assessment (HRA) in maintenance of production process: a case study. International Journal of System Assurance Engineering and Management, 7(2), $229-238$. https://doi.org/10.1007/s13198-016-0453-z

Abbassi, R. Khan, F., Garaniya, V., Chai, S., Chin, C., \& Hossain, K.A. (2015). An integrated method for human error probability assessment during the maintenance of offshore facilities. Process Safety and Environmental Protection, 94(C), 172-179. https://doi.org/10.1016/j.psep.2015.01.010

Bao, M., \& Ding, S. (2014). Individual-related factors and Management-related factors in Aviation Maintenance. $3 r d$ International Symposium on Aircraft Airworthiness (IS AA 2013) (80, 293-302).

https://doi.org/10.1016/j.proeng.2014.09.088

Bao, Y., Wang, Y., Huang, G., Xia, J., Chen, J., \& Guo, C. (2015). Impact of Human Error on Electrical Equipment Preventive Maintenance Policy. In 2015 IEEE Power \& Energy Society General Meeting. https://doi.org/10.1109/PESGM.2015.7285939

Boring, R.L. (2009). Reconciling resilience with reliability: The complementary nature of resilience engineering and human reliability analysis. 1589-1593. In Proceedings of the Human Factors and Ergonomics Society Annual Meeting, 53(20), 1589-1593. https://doi.org/10.1177/154193120905302010 
Boring, R.L. (2010). How Many Performance Shaping Factors are Necessary for Human Reliability Analysis? In Proceedings of the 10th International Probabilistic Safety Assessment and Management Conference.

Bozkurt, Y., \& Kavsaoglu, M.S. (2010). MEDA case study for an MRO. In 10th ALAA Aviation Technology, Integration and Operations Conference (2). https://doi.org/10.2514/6.2010-9208

Castiglia, F., \& Giardina, M. (2013). Analysis of operator human errors in hydrogen refuelling stations: Comparison between human rate assessment techniques. International Journal of Hydrogen Energy, 38(2), 1166-1176. https://doi.org/10.1016/j.ijhydene.2012.10.092

Chen, W., \& Huang, S. (2014). Human Reliability Analysis for Visual Inspection in Aviation Maintenance by a Bayesian Network Approach. Transportation Research Record, 2449(2449), 105-113. https://doi.org/10.3141/2449-12

Chen, W., \& Huang, S.P. (2013). Human reliability analysis in aviation maintenance by a bayesian network approach. Proceedings of the 11th International Conference on Structural Safety and Reliability (ICOSS AR), (2091-2096).

Dhillon, B.S. \& Liu, Y. (2006). Human error in maintenance: A review. Journal of Quality in Maintenance Engineering, 12(1), 21-36. https://doi.org/10.1108/13552510610654510

Dhillon, B.S. (2009). Human reliability and error in maintenance. Handbook of Maintenance Management and Engineering, 695-710. https://doi.org/10.1007/978-1-84882-472-0_25

Dhillon, B.S. (2014). Human error in maintenance: An investigative study for the factories of the future. In IOP Conference Series: Materials Science and Engineering. https://doi.org/10.1088/1757-899X/65/1/012031

Di Pasquale, V., Miranda, S., Iannone, R., \& Riemma, S. (2015a). A Simulator for Human Error Probability Analysis (SHERPA). Reliability Engineering and System Safety, 139, 17-32. https://doi.org/10.1016/j.ress.2015.02.003

Di Pasquale, V., Miranda, S., Iannone, R., \& Riemma, S. (2015b). An HRA-based simulation model for the optimization of the rest breaks configurations in human-intensive working activities. IFAC-PapersOnLine, 48(3), 332-337. https://doi.org/10.1016/j.ifacol.2015.06.103

Di Pasquale, V., Miranda, S., Iannone, R., \& Riemma, S. (2015c). Simulative analysis of performance shaping factors impact on human reliability in manufacturing activities. 27th European Modeling and Simulation Symposium.

Di Pasquale, V., Franciosi, C., Lambiase, A., \& Miranda, S. (2017a). Methodology for the analysis and quantification of human error probability in manufacturing systems. Student Conference on Research and Development (SCOReD) (1-5).

Di Pasquale, V., Franciosi, C., Iannone, R., Malfettone, I., \& Miranda, S. (2017b). Human error in industrial maintenance: a systematic literature review. In XXII Summer School Francesco Turco (164-170).

Di Pasquale, V., Fruggiero, F., Iannone, R., \& Miranda, S. (2017c). A model for break scheduling assessment in manufacturing systems. Computers \& Industrial Engineering, 111, 563-580. https://doi.org/10.1016/j.cie.2017.05.017

Di Pasquale, V., Miranda, S., Neumann, W.P., \& Setayesh, A. (2018). Human reliability in manual assembly systems: a Systematic Literature Review. IFAC-PapersOnLine, 51(11), 675-680. https://doi.org/10.1016/j.ifacol.2018.08.396

Franciosi, C., Lambiase, A., \& Miranda, S. (2017). Sustainable maintenance: a periodic preventive maintenance model with sustainable spare parts management. IFAC-PapersOnline, 50 (1), 13692-13697. https://doi.org/10.1016/j.ifacol.2017.08.2536

Franciosi, C., Iung, B., Miranda, S., \& Riemma, S. (2018). Maintenance for Sustainability in the Industry 4.0 context: a Scoping Literature Review. IFAC-PapersOnLine, 51(11), 903-908. https://doi.org/10.1016/j.ifacol.2018.08.459

Geibel, W.D., Von Thaden, T.L., \& Suzuki, T. (2008). Issues that precipitate errors in airline maintenance. In Proceedings of the Human Factors and Ergonomics Society (1, 94-98). https://doi.org/10.1177/154193120805200121

Gertman, D., Blackman, H., Marble, J., Byers, J., \& Smith, C. (2004) The Spar-H Human Reliability Analysis Method. US Nuclear Regulatory Commission.

Gibson, G. P. (2000). Improving maintenance through reducing human error. In Cottam, M.P., Pape, R.P., \& Harvey, D. (Eds.), Foresight and Precaution, 1-2, 399-404. 
Hameed, A., Khan, F., \& Ahmed, S. (2016). A risk-based shutdown inspection and maintenance interval estimation considering human error. Process Safety and Environmental Protection, 100, 9-21.

https://doi.org/10.1016/j.psep.2015.11.011

Hayama, K., Miyachi, Y., Nakamura, R., Shibata, T., \& Kimura, H. (2011). Method to support risk management of human error in track maintenance work. Quarterly Report of RTRI (Railway Technical Research Institute) (Japan), 52(3), 168-173. https://doi.org/10.2219/rtriqr.52.168

Heo, G., \& Park, J. (2010). A framework for evaluating the effects of maintenance-related human errors in nuclear power plants. Reliability Engineering \& System Safety, 95(7), 797-805. https://doi.org/10.1016/j.ress.2010.03.001

Hobbs, A., \& Williamson, A. (2002). Skills, rules and knowledge in aircraft maintenance: Errors in context. Ergonomics, 45(4), 290-308. https://doi.org/10.1080/00140130110116100

Hobbs, A., \& Williamson, A. (2003). Associations between errors and contributing factors in aircraft maintenance. Human Factors, 45(2), 186-201. https://doi.org/10.1518/hfes.45.2.186.27244

Hobbs, A., Williamson, A., \& Van Dongen, H.P.A. (2010). A circadian rhythm in skill-based errors in aviation maintenance. Chronobiology International, 27(6), 1304-1316. https://doi.org/10.3109/07420528.2010.484890

Hollnagel, E. (1998). Cognitive Reliability and Error Analysis Method (CREAM). Cognitive Reliability and Error Analysis Method (CREAM), 1-21. https://doi.org/10.1016/B978-008042848-2/50001-4

Islam, R., Abbassi, R., Garaniya, V., \& Khan, F. I. (2016). Determination of human error probabilities for the maintenance operations of marine engines. Journal of Ship Production and Design, 32(4), 226-234.

https://doi.org/10.5957/JSPD.32.4.150004

Islam, R., Yu, H., Abbassi, R., Garaniya, V., \& Khan, F. (2017). Development of a monograph for human error likelihood assessment in marine operations. Safety Science, 91, 33-39. https://doi.org/10.1016/j.ssci.2016.07.008

Kim, J., \& Park, J. (2008). Task types and error types involved in the human-related unplanned reactor trip events. Nuclear Engineering and Technology, 40(7), 615-624. https://doi.org/10.5516/NET.2008.40.7.615

Kim, J., \& Park, J. (2009). Characteristics of test and maintenance human errors leading to unplanned reactor trips in nuclear power plants. Nuclear Engineering and Design, 239(11), 2530-2536.

https://doi.org/10.1016/j.nucengdes.2009.06.010

Kim, J., \& Park, J. (2012). Reduction of test and maintenance human errors by analyzing task characteristics and work conditions. Progress in Nuclear Energy, 58, 89-99. https://doi.org/10.1016/j.pnucene.2012.02.002

Kirwan, B. (1996). The validation of three human reliability quantification techniques - THERP, HEART and JHEDI: Part I - technique descriptions and validation issues. Applied Ergonomics, 27(6), 359-373. https://doi.org/10.1016/S0003-6870(96)00044-0

Kolaczkowski, A., Forester, J., Lois, E., \& Cooper, S. (2005). Good Practices for Implementing Human Reliability Analysis (HRA). U.S. Nuclear Regulatory Commission

Kovacevic, S., Papic, L., Janackovic, G.L., \& Savic, S. (2016). The analysis of human error as causes in the maintenance of machines: a case study in mining companies. South African Journal of Industrial Engineering, 27(4), 193-202. https://doi.org/10.7166/27-4-1493

Kumar, V.N.A., \& Gandhi, O.P. (2011). Quantification of Human Error in Maintenance Using Graph Theory and Matrix Approach. Quality and Reliability Engineering International, 27(8), 1145-1172. https://doi.org/10.1002/qre.1202

Kumar, V.N.A., Gandhi, M.S., \& Gandhi, O.P. (2015). Identification and Assessment of Factors Influencing Human Reliability in Maintenance Using Fuzzy Cognitive Maps. Quality and Reliability Engineering International, 31(2), 169-181. https://doi.org/10.1002/qre.1569

Latorella, K.A. \& Prabhu, P.V. (2000). A review of human error in aviation maintenance and inspection. International Journal of Industrial Ergonomics, 26(2), 133-161. https:/ / doi.org/10.1016/S0169-8141(99)00063-3 
Liang, G.F., Lin, J.T., Hwang, S.L., Wang, E.M.Y., \& Patterson, P. (2010). Preventing human errors in aviation maintenance using an on-line maintenance assistance platform. International Journal of Industrial Ergonomics, 40(3). https://doi.org/10.1016/j.ergon.2010.01.001

Lind, S. (2008). Types and sources of fatal and severe non-fatal accidents in industrial maintenance. International Journal of Industrial Ergonomics, 38(11-12), 927-933. https://doi.org/10.1016/j.ergon.2008.03.002

McDonnell, D., Balfe, N., Baraldi, P., \& O’Donnell, G. E. (2015). Reducing Uncertainty in PHM by Accounting for Human Factors - A Case Study in the Biopharmaceutical Industry. In Proceedings of the 4th International Conference on through-life engineering services (38, 84-89). https://doi.org/10.1016/j.procir.2015.08.003

Neumann, W.P., Kolus, A. \& Wells, R.P.W. (2016). Human Factors in Production System Design and Quality Performance - A Systematic Review. IFAC-PapersOnLine, 49(12), 1721-1724.

https://doi.org/10.1016/j.ifacol.2016.07.830

Nicholas, C. (2009). Human error in maintenance - A design perspective. Handbook of Maintenance Management and Engineering.

Noroozi, A., Abbassi, R., MacKinnon, S., Khan, F., \& Khakzad, N. (2013a). Effects of Cold Environments on Human Reliability Assessment in Offshore Oil and Gas Facilities. The Journal of the Human Factors and Ergonomics Society, 56(5), 825-839. https://doi.org/10.1177/0018720813512328

Noroozi, A., Khakzad, N., Khan, F., MacKinnon, S., \& Abbassi, R. (2013b). The role of human error in risk analysis: Application to pre- and post-maintenance procedures of process facilities. Reliability Engineering \& System Safety, 119, 251-258. https://doi.org/10.1016/j.ress.2013.06.038

Noroozi, A., Abbassi, R., MacKinnon, S., Khan, F., \& Khakzad, N. (2014). Effects of cold environments on human reliability assessment in offshore oil and gas facilities. Human Factors, 56(5).

https://doi.org/10.1177/0018720813512328

Okoh, P. (2015). Maintenance grouping optimization for the management of risk in offshore riser system. Process Safety and Environmental Protection, 98. https://doi.org/10.1016/j.psep.2015.06.007

Papic, L., \& Kovacevic, S. (2016). Human factor in mining machines maintenance operations. In Proceedings - 2nd International Symposium on Stochastic Models in Reliability Engineering, Life Science, and Operations Management, SMRLO. https://doi.org/10.1109/SMRLO.2016.80

Patriarca, R., Bergström, J., Di Gravio, G., \& Costantino, F. (2018). Resilience engineering: Current status of the research and future challenges. Safety Science. 102(October 2017), 79-100. https://doi.org/10.1016/j.ssci.2017.10.005

Pires, S., Sénéchal, O., Deschamps, F., Loures, E.F.R., \& Perroni, M.G. (2015). Industrial maintenance for sustainable performance: A systematic literature review. 23rd International Conference for Production Research (ICPR).

Rankin, W., Hibit, R., Allen, J., \& Sargent, R. (2000). Development and evaluation of the Maintenance Error Decision Aid (MEDA) process. International Journal of Industrial Ergonomics, 26(2), 261-276.

https://doi.org/10.1016/S0169-8141(99)00070-0

Rashid, H.S. J., Place, C.S., \& Braithwaite, G.R. (2013). Investigating the investigations: A retrospective study in the aviation maintenance error causation. Cognition, Technology and Work, 15(2). https://doi.org/10.1007/s10111-011-02107

Rashid, H.S. J., Place, C.S., \& Braithwaite, G.R. (2014). Eradicating root causes of aviation maintenance errors: Introducing the AMMP. Cognition, Technology and Work, 16(1). https://doi.org/10.1007/s10111-012-0245-4

Razak, I.H.A., Kamaruddin, S., \& Azid, I.A. (2008). Development of Human Reliability Model for evaluating maintenance workforce reliability: A case study in electronic packaging industry. In Proceedings of the IEEE/CPMT International Electronics Manufacturing Technology (IEMT) Symposium. 
Singh, S., \& Kumar, R. (2015). Evaluation of human error probability of disc brake unit assembly and wheel set maintenance of Railway Bogie. In 6th International Conference on Applied Human Factors and Ergonomics (AHFE) (3041-3048). https://doi.org/10.1016/j.promfg.2015.07.849

Sheikhalishahi, M., Azadeh, A., Pintelon, L., Chemweno, P., \& Ghaderi, S.F. (2016). Maintenance Scheduling Optimization in a Multiple Production Line Considering Human Error. Human Factors and Ergonomics in Manufacturing \& Service Industries, 26(6), 655-666. https://doi.org/10.1002/hfm.20405

Swain, A.D. \& Guttmann, H.E. (1983). Handbook of Human Reliability Analysis with Emphasis on Nuclear Power Plant Applications, NUREG/CR 1278.

Zhou, X., Zhou, D., Guo, Z., \& Zhang, W. (2015). A Cognitive Reliability Assessment Method For Aviation maintenance Error. In Proceedings of the 2015 First International Conference on Reliability Systems Engineering (ICRSE).

Journal of Industrial Engineering and Management, 2019 (www.jiem.org)

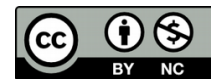

Article's contents are provided on an Attribution-Non Commercial 4.0 Creative commons International License. Readers are allowed to copy, distribute and communicate article's contents, provided the author's and Journal of Industrial Engineering and Management's names are included. It must not be used for commercial purposes. To see the complete license contents, please visit https://creativecommons.org/licenses/by-nc/4.0/. 